\title{
7. Ministers and Scandals
}

\author{
Scott Brenton
}

Sharp and Jull resigned. Labor led the Coalition two goals to nil.

- Sydney Morning Herald, 6 October 1997

Typifying the media commentary surrounding ministerial resignations, politics is often reported like a sporting contest. During Liberal Prime Minister John Howard's first term of office, the use and misuse of politicians' travel entitlements - which the media quickly dubbed 'travel rorts'-became the theme of a series of scandals. Transport Minister, John Sharp, voluntarily amended his travel claims and repaid almost $\$ 9000$, but did not publicly disclose this information; neither did the Administrative Services Minister, David Jull, who oversaw the amendment and repayment. The Coalition initially closed ranks, emphasising Sharp's 'good bloke factor' and the voluntary nature of the rectifications, as they tried to protect one of the National Party's rising stars. The Government was, however, having 'mid-term blues' and Sharp lost the Prime Minister's support. Both he and Jull were asked to resign, with Howard proclaiming that 'I have acted to uphold not only the reality of standards, but also the perception of standards and that is why what has happened has occurred' (The Australian, 25 September 1997). While Howard was not the first prime minister to use such standards to sanction a minister, he became the first to explicitly define the standards and, perhaps inadvertently, enabled opponents to define contraventions of them as scandals with equivalent certainty.

\section{The History of Scandals}

While the first written account of a scandal in ancient Greece is almost as old as democracy itself, and scandals have long been a feature of liberal-democratic politics (Clark 2003; Neckel 2005), the involvement of Australian ministers in publicised scandals and the increasing frequency with which they occur are relatively recent phenomena. Both rumours and factual stories about the private lives of former prime ministers have entered political folklore but went unreported at the time: John Curtin was a (recovering) alcoholic and had been imprisoned during World War I; Ben Chifley had an affair with his personal secretary; Robert Menzies had an affair with a prominent newspaper proprietor's wife; Harold Holt had been drinking with a woman who was not his wife before his disappearance in the ocean; John Gorton was also an alcoholic; and Billy 
McMahon enjoyed the company of young male sailors. As Dowding, Lewis and Packer chronicle in Chapter 6, in the few decades of the postwar period, Australian politics was characterised by stable conservative government and the more sensational resignations were due to breaches of cabinet solidarity and leadership instability after Prime Minister Robert Menzies retired, rather than the types of indiscretions that now make headlines. The election of a more radical government under Labor Prime Minister Gough Whitlam in 1972 stimulated new political tactics: the targeting of individual ministers in order to challenge the legitimacy and competence of the government, and the fitness of the leader to continue as prime minister.

As the incidence of political scandals has increased, the role of the mass media has changed, while scandalous allegations are being used as offensive political weapons (Williams 1998). In the final year of the Whitlam Government preceding the constitutional crisis, the questionable appointment of Junie Morosi as Deputy Prime Minister and Treasurer Jim Cairns' Principal Private Secretary sparked rumours of a sexual relationship. More significant was Cairns' involvement, along with Minerals and Energy Minister, Rex Connor, in what became known as the 'loans affair'. The scandal centred on attempts to secure loans from Middle Eastern businessman Tirath Khemlani, rather than using the Treasury's normal channels through the Loan Council. For the Opposition and sections of the media, calls for resignation were part of legitimately holding the Government to account. The Governor-General's dismissal of the Whitlam Government confirmed the effectiveness of such offensive political tactics and demonstrated that a government could be brought down by scandal.

Prime Minister Malcolm Fraser's Coalition government was comparatively less scandal-ridden, but increasingly behaviour outside the strict confines of ministers' portfolio responsibilities was being scrutinised. Most notably, Health Minister Michael MacKellar became embroiled in controversy over incorrect customs declaration forms on an imported colour television set, and eventually resigned along with the minister responsible for customs, John Moore.

During Bob Hawke's prime ministership, spanning almost nine years, there were only three resignations due to scandals, and only one during Paul Keating's first two years as prime minister. Strikingly, during the second term of the Keating Labor Government there were five such resignations and many more controversial affairs where ministers resisted calls to resign (termed non-resignations). One of the most notable was that of NSW right factional powerbroker Graham Richardson, who was instrumental in helping Keating depose Hawke. The business dealings of Richardson's cousin by marriage Greg Symons, and Richardson's alleged interventions to assist him, came under scrutiny. Richardson's response was defiant: 
Obviously over the years I have hurt them [the Opposition] and they think the Government would be weakened if they got rid of me. They know I am close to Paul Keating and they are trying guilt by association and they will try to extend it further to Paul. (The Australian, 6 May 1992)

Howard, at the time a shadow minister, was one of Richardson's chief critics in Parliament, arguing that ' $[\mathrm{t}]$ here is no more serious parliamentary offence than a minister lying to the Parliament. That is what has happened on this occasion' (Sydney Morning Herald, 9 May 1992). During the previous 17 years, four ministers had been accused of 'misleading the Parliament'; all were forced to resign from their ministries. In a speech to Parliament, Howard explicitly linked ministerial conduct to prime ministerial leadership:

Under questioning from the Opposition, and not as an act of ministerial contrition and coming clean, we heard his story. If he had come into the Parliament and said, 'Look, I have really stuffed this one up. I did not give a full account, and here is the full story' perhaps we on this side of Parliament may have a different attitude...

He is a legendary member of the 'mates', and they operate on the basis of never apologising and never resigning. It is not surprising therefore that the Prime Minister should be trying to tough this one out. But, at the end of the day, he has to realise that he stands in a long line of prime ministers, from both sides, who, when the crunch finally comes, have normally done the right thing.

Gough Whitlam, with all his weaknesses, had the guts to sack Rex Connor because he inadvertently misled the Parliament. He had the guts to sack Jim Cairns because he, inadvertently or otherwise, misled the Parliament and his Prime Minister. We want to know whether Paul Keating has the guts to sack Senator Richardson because he misled the Senate...

The supreme test of the courage and probity of the Prime Minister is whether he insists on ministers observing the basic requirements of a minister; that is, that they tell the Parliament the truth. Senator Richardson has failed to do this. (Sydney Morning Herald, 9 May 1992)

Howard argued that:

He [Senator Richardson] is too strong to dismiss. The Prime Minister is bound body and soul to his factional mate and can't get rid of him for 
that reason. It's got nothing to do with the merits of the issue...It's got everything to do with the dominant role that...Richardson played in getting Paul Keating the job. (The Canberra Times, 11 May 1992)

These events illustrated the narrative of an ailing government losing its way and a leader losing control over his ministers. Howard effectively appropriated the issue of ministerial propriety as a central campaign theme when he subsequently became Opposition Leader, promising higher standards of ministerial conduct when he won office in 1996. He became the first Australian prime minister to institute a ministerial code of conduct based on a publicly available document, entitled A Guide on Key Elements of Ministerial Responsibility (McKeown 2009). It was not just a codification of the public's expectations of ministerial behaviour, but also explicitly detailed what Howard as leader expected. While there were criticisms that the document lacked legal, regulatory or parliamentary authority, and that Howard was the sole authority as author, arbiter and interpreter (Uhr 1998), it concomitantly meant that Howard's authority was also called into question when ministers breached the code. Furthermore, as a Liberal prime minister with the power to choose his own ministers, Howard's judgment in selecting appropriate ministers could also be scrutinised.

\section{What Is a Political Scandal?}

One of the most common definitions in the field of 'scandology' - as the study of scandals has become known - is that political scandals involve 'the gross violation of cultural and [or] legal norms that limit the use of positions of public trust for private purposes' (Logue 1988, 257). Political scandals can occur only in liberal democracies, as freedom of speech, an open and aggressive media and strong political competition are necessary conditions enabling scandals to flourish. Moreover, scandals occur at the intersection of power with the processes and procedures that are so fundamental in liberal democracies (Markovits and Silverstein 1988). The defining characteristic of a political scandal is not the degree of personal gain, but the violation of process and procedure in the quest for greater political power. Simply using public office for individual gain is not scandalous, as most politicians are rational, materially self-interested individuals attracted to the benefits of power; noblesse oblige motivates few (Logue 1988). Rather it is the extent to which rules and regulations attached to public office are violated.

Processes and procedures are also fundamental components of accountability, and therefore scandalous transgressions are often erroneously, or at least simplistically, linked to questions of accountability. Scandals are not, however, really about ministerial accountability; rather they are tests of prime ministerial 
leadership. Being called to account in response to a scandal is often reduced to a simplistic question of should the minister resign/be sacked. Yet sanctions are only part of accountability. Sanctions are about punishment and, as in the earlier case of 'travel rorts', about political point-scoring. Accountability involves not simply questioning the transgressor and the transgression and debating the consequences, but a deeper questioning of the processes and procedures and how these can be abused through the exercise of power. This did not occur, and rarely does. The system of travel and other entitlements remained open to abuse and the political saga continued unabated. Only days after the resignations of Sharp and Jull, the Opposition refocused its attention on the travel claims of Veterans' Affairs Minister, Bruce Scott, but could not gain traction in the media; however, another Nationals minister was already in their sights. Labor shadow minister Simon Crean interrogated Science and Technology Minister, Peter McGauran, in Question Time over his travel claims, and warned that the Opposition would keep scrutinising his claims until he resigned (The Australian, 24 September 1997).

\section{Game on: Winning ministerial 'scalps' and claiming momentum}

Oppositions are not interested in explanations or justifications or any other form of accounting for one's actions, and will generally always call for the minister to resign or be sacked. McGauran's responses, like those of Sharp and Jull before him, were secondary: the real focus was on what the leaders knew, should have known or did not know and how they handled the situation. At first, Howard and the National Party leader, Tim Fischer, defended McGauran. Howard, however, later requested a full audit of McGauran's travel claims and charter allowances. Fischer conceded that the minister's actions were 'prima facie... unacceptable' (The Australian, 24 September 1997), and that McGauran initially misled Parliament. After the audit Howard told Parliament that his office was informed a few months previously about incorrect travel claims by two ministers, but, he claimed, 'I personally knew nothing of the matters until the past few days' (The Australian, 24 September 1997). Howard's senior members of staff Graham Morris and Fiona McKenna were sacked and McGauran finally tendered his resignation to the Prime Minister. This was a decisive leadership action, with an element of personal sacrifice in dismissing trusted senior advisers.

The Government had already been tarnished by the 'shares affair' in the preceding year. Assistant Treasurer, Jim Short, resigned from the ministry in 1996 after granting a banking licence to a subsidiary of a bank in which he held shares. Parliamentary Secretary to the Treasurer, Senator Brian Gibson, also 
resigned in 1996 after granting futures market access to a company in which he held shares. In 1997, Small Business Minister, Geoff Prosser, resigned over perceived conflicts of interest due to his continued private business dealings. Resources Minister, Senator Warwick Parer, also became embroiled in a similar scandal and eventually ceded control of mining shares and other investments. With 'travel rorts', Labor was beginning to master a damaging political strategy, with a complicit media also fanning populist anti-politician sentiment, which was particularly strong when it came to taxpayer-funded entitlements and resources. While often dismissed as trivial distractions from 'serious' political issues, the focus of political competition has shifted to trivial issues in general (Apostolidis and Williams 2004). Williams argues that many consumers of the mass media find policy details and differences complex and boring, whereas scandalous allegations are simpler to report and are generally regarded as being more interesting (Williams 1998). Political scandals do not require detailed political knowledge and can enliven discussions in forums like talkback radio, in contrast with the arid, abstract policy discussions that can create a barrier to popular involvement (Clark 2003).

Each scandal also has its own momentum, which is crucial in determining its longevity and the potential damage, and is also dependent on the discovery of new pieces of information. Innuendo and suggestion are habitually used to develop momentum until new information is discovered, particularly when the initial facts seem mundane; scandal momentum is often related to sheer sensationalism (Garment 1991). Momentum is closely related to the news cycle and what other issues are on the media agenda at the time. The life of scandals is not determined by the nature of the offence, but by the interaction of political strategies and media practices, which each function according to their own logics and sets of interests (Tiffen 1999). Often rumours have been circulating behind the scenes for some time and the instigator chooses a specific moment to publicise the gossip, with the timing planned to divert attention from other issues or to link the scandal to particular political agendas (Clark 2003). Rumours and gossip can also be suppressed until the politician is perceived to be a real threat to opponents, such as when they are promoted to a leadership or ministerial position.

While the momentum of a single scandal can be broken by a resignation or the diversion of media attention to other issues, there is a cumulative effect and the next scandal can be even more damaging. The opposition will continue to fossick for damaging information on other ministers under the guise of raising standards of accountability, in order to whittle away the prime minister's moral authority and keep party leaders on the defensive. It is not in the raw political interests of the opposition for processes and procedures to be fundamentally reformed to prevent future abuses; rather it is in their interests for abuses to 
occur and be exposed - unless their own members are involved, enabling the government side to raise the spectre of mutually assured destruction. In this case, not only can the overall political momentum be broken, the scandalous issue can be taken off the agenda. The Government 'successfully' turned defence into offence by questioning the travel claims of Labor shadow minister Senator Nick Sherry. Sherry attempted suicide, which became the circuit-breaker for an uneasy truce. The Opposition relented as they realised that the most effective political prosecutor is the media.

\section{'It's Not a Hanging Offence'}

In 2000, The Canberra Times journalist Emma Macdonald broke the story that in late 1993 Peter Reith (by this stage the Minister for Employment, Workplace Relations and Small Business) gave his parliamentary telecard code number to his son, Paul, to contact him in an emergency while in Western Australia on holiday. His son used it for four years, making $\$ 950$ worth of calls; however, 11000 phone calls from 900 locations around the world, costing nearly $\$ 50$ 000, were made on the telecard over six years from 1994 to 1999. Reith told the Prime Minister, who referred the matter to the Australian Federal Police, while a whistleblower informed Labor Senators John Faulkner and Robert Ray at about the same time as Howard was initially told (The Australian, 12 October 2000). The behind-the-scenes actions led to criticisms that there was a lack of public accountability during the 14-month secret investigation.

The Director of Public Prosecutions did not find sufficient evidence to lay any charges. The Commonwealth Director of Public Prosecutions found that Reith's son was not criminally liable, and the Australian Federal Police and the Commonwealth Director of Public Prosecutions cleared Reith of criminal liability. The Commonwealth Solicitor-General, David Bennett, also cleared Reith and his son of liability for most of the debt (except the \$950) after finding that a court would most likely prefer Paul Reith's version of events; however, before the final report was released, Reith paid the entire debt by taking out a loan, without claiming a work-related tax deduction (after earlier refusing to rule out that possibility). Reith said that '[t]he responsibility I'm accepting is a political one, not a moral one, whilst acknowledging my first mistake, a mistake anybody else could reasonably have made' (Sydney Morning Herald, 16 October 2000).

Reith appeared to breach a number of clauses in the Prime Minister's code of conduct, particularly that '[m]inisters should ensure that their actions are calculated to give the public value for money and never abuse the privileges, which, undoubtedly, are attached to ministerial office' (The Australian, 14 
October 2000). Yet Reith said he had not considered resigning. Howard would not sack Reith because it was not a 'hanging offence' although he said Reith had been foolish (Sydney Morning Herald, 27 October 2000). Some Coalition Members of Parliament were unhappy with Reith's handling of the incident, calling for Howard to sack him from the ministry to limit damage to the Prime Minister's credibility (The Australian, 20 October 2000; Daily Telegraph, 23 October 2000).

An unnamed Labor source claimed the party wanted to vigorously pursue Reith and Howard, but not to the point where their own practices would be scrutinised (Sunday Telegraph, 15 October 2000). Notably, Labor did not pursue the issue when their senators were first informed, as their strategy appeared to be to encourage the media to take the lead, giving the public the sense that it was a non-partisan exercise. The Canberra Times (20 October 2000) editorialised that:

The media was crucial, eventually, in Reith's decision to pay back the $\$ 50,000 \ldots$ Everyone was waiting to see what the media, through editorials, talkback radio and public-opinion polls, had to say about the matter. Talkback radio concluded that Reith should pay up...The overall impression is that ministers and their leaders wait to see what they can get away with rather than take a principled decision.

In Howard's first two years as prime minister there were seven resignations in response to scandals, while there was none in the next four years and only three during the remainder of Howard's prime ministership. This was despite frequent scandals and calls for resignation. One such scandal centred on the Minister for Revenue and Assistant Treasurer, Senator Helen Coonan, and her spouse's property investments and principal residences. Coonan claimed her incorrect pecuniary interest declaration was due to a typographical error, but admitted that she mistakenly declared her principal place of residence as an investment property. The Opposition then alleged a conflict of interest between Coonan's ministerial duties and her directorship of a mediation company. Coonan claimed that she resigned as a director when she became a minister, although her spouse, the company's secretary, did not so advise the Australian Securities and Investments Commission until 11 months later. It also emerged that Coonan used her ministerial letterhead for personal purposes. She used it to pursue a personal insurance claim, to complain to the local council and to a builder, and to (successfully) request that the council waive a supplementary development application fee. Howard conceded that the use of ministerial letterhead for personal affairs was 'not normal practice' and 'I encourage ministers not to do it', but argued that it was not a 'hanging offence' (Sydney Morning Herald, 14 December 2002). He said that Coonan was not in breach of his ministerial code of conduct. 
Another non-resignation involved the Minister for Regional Services, Territories and Local Government, Wilson Tuckey. Tuckey used his ministerial letterhead to assert to the SA Police Minister that 'his constituent' - Tuckey's son-should have been given a warning rather than a fine for failing to carry a logbook for his truck (The Canberra Times, 23 August 2003). Tuckey initially told Parliament that: 'I wrote to the minister saying that I thought a warning should be appropriate...I did not press the matter any further', triggering accusations that he was misleading Parliament, as a Labor backbencher revealed a series of letters (Sydney Morning Herald, 20 August 2003; The Canberra Times, 23 August 2003).

This time Labor was more active in pursuing the issue, particularly after the last non-resignation. Labor accused Tuckey of breaching Howard's code of conduct, which stated that ministers should 'avoid giving any appearance of using public office for private purposes', and that '[m]inisters should not exercise the influence obtained from their public office, or use official information, to gain improper benefit for themselves or another' (The Canberra Times, 23 August 2003). Howard's ministerial code of conduct was also subjected to media scrutiny, with criticisms that it had become meaningless (Daily Telegraph, 21 August 2003). Howard's response was 'I thought the minister was quite foolish and wrong, he was very foolish indeed to have written this on his ministerial letterhead', but it was not 'a hanging offence' (The Canberra Times, 23 August 2003).

Resignations or sackings are viewed as a win for the opposition or a 'scalp', and important in gaining 'momentum'. Thus, ministers and prime ministers initially adopt a defensive strategy - a position, once adopted, that becomes hard to shift from. The choice for the government is based on whether a prolonged distraction is giving the opposition more momentum than a resignation would. The extent of the distraction is not necessarily related to the actual transgression or degree of culpability, but rather what other issues the scandal is competing with for political and media attention at the time. If a scandal ends in resignation (which is uncommon), the government frames it as a noble gesture on the part of the minister to end the distraction to the government and its policy focus. The other common outcome is a cabinet reshuffle, which is again framed in positive terms, like refreshing the government. Tuckey was eventually demoted from the ministry in a reshuffle only a month after the scandal.

Howard's responses to scandals later in his prime ministership often followed the same theme. He repeatedly defended ministers - Reith, Coonan and Tuckeyon the grounds that the behaviour in question was not a 'hanging offence'. His reluctance to demote ministers can be viewed in purely political terms, as evidence of his determination not to give the Opposition a 'scalp'. Presumably government strategists decided that it was less damaging to defend ministers 
than to force resignations and allow the Opposition to claim small victories and gain momentum. Scandals do eventually run out of steam as new political issues take prominence, so determined ministers can avoid resignation.

Keating, too, was very reluctant to dismiss his scandal-ridden minister Graham Richardson, until the issue became too distracting for the Government. Keating displayed a similar attitude towards Sports Minister, Ros Kelly, in what became known as the 'sports rorts affair', after accusations that she bypassed process in approving sports grants for marginal Labor electorates and then misled Parliament in response to questions. At the time even Kim Beazley, later to become Labor leader, conceded that misleading Parliament is a 'hanging offence'.

\section{Limiting the Damage}

Scandals create opportunities for considerable political damage by distracting the politician, their party, the media and the public from other political issues of the day. The political damage is in proportion to the extent of the distraction. Timing is therefore a significant factor. When a scandal breaks, the gravity of the transgression and the standing of the politician will be compared with the importance of other issues currently on the political agenda to determine whether the scandal is given the opportunity to develop momentum and become a distraction. These comparisons will be made both strategically and more passively by various groups, principally political opponents, the media and the public. Often those groups will differ in their interpretations, which may mitigate the severity of the damage.

The magnitude of the scandal does not necessarily dictate the extent of the distraction, as there are other more important factors at play. It is when that distraction interrupts the politician's ability to effectively continue in their position that it becomes career threatening or career destroying. That decision is not made by the media or even the public (except at election time), but by the politician and more importantly the politician's party and leader. The other aspect of this issue is that a scandal can be damaging even if there is no tangible evidence of harm done to the politician's prospects. It is the perception that it could potentially be a problem that is damaging. Scandals can dominate the limited and precious media time given to federal politics each day, and deprive party leaders of opportunities to discuss other issues. Political discourse, at least in the electronic media, is often reduced to 10-second sound bites and in this environment a political scandal is an unnecessary distraction.

Most ministers actually survive scandals, so it is perhaps more instructive to examine why the politicians whose political careers ended as a result of scandals sustained such significant damage. The overall impact of scandals has generally 
not been felt at the ballot box, but rather has been mitigated or intensified during the normal course of politics as parties seek to attack and counterattack their rivals (with the media ever present). While public support is ultimately necessary for political survival, it is the support that the politician's party provides (or does not) that is most crucial. Scandals alone do not cause the political distraction; rather the overall handling of the scandal beyond just the verbal response is what determines the level of damage. Resignations can be the most damaging outcome for a government, creating the impression that ministers are incompetent, whereas by weathering the controversy ministers and prime ministers can suggest that scandals are part of the 'rough and tumble' of politics and that they are tough enough to handle this. Howard's repeated defence of his ministers, perhaps counter-intuitively, did not lose its effectiveness over time: those familiar words did not appear to remind voters of previous ministerial indiscretions during his prime ministership or indicate a lack of discipline.

A scandal does not necessarily end a minister's career, and long-term damage can be limited. There are many political factors beyond the immediate control of the politician that can mitigate the damage. First, the support of the party is crucial, as the politician's chance of winning a seat as an independent is minimal. Furthermore, strong and publicly expressed support from the party is required, as its absence is noticeable. This can send a message to the public that there is something seriously wrong with the behaviour of the politician, if even his or her party is unforgiving. Second, the timing will determine the amount of potential media attention, and this is beyond the control of the politician and their party. Third, major-party senators (in the States) enjoy the advantage of six-year terms and generally safer seats, which makes it more likely they will have their party's support to weather any storms. Fourth, complicated scandals where simple narratives cannot be applied, as in the case of Coonan, are unlikely to excite public interest. Fifth, the public cares less than might be expected. Politicians are already held in low regard, so scandals are not shocking in that sense. Furthermore, during election campaigns other issues assume more public importance. Finally, a politician may be able to survive a scandal by providing a sense of closure. Resigning from a ministerial or leadership position is one way; he or she might also repay money or in some other way move to repair the damage. Such acts can also provide a socially acceptable ending to the story. Significantly, most scandals do not have long-term political impacts.

Ministers are held to a higher standard of personal and professional behaviour than other parliamentarians. Ministers are called to resign from the ministry, but rarely from parliament altogether. Similarly, there is no 'punishment' for backbenchers who may commit the same offence as a minister, such as incorrectly claiming an entitlement. Public expectations are heightened to some degree by frequent opposition promises of improved ministerial codes of 
conduct. As Thompson $(2005,47)$ observes, 'the occurrence of scandal tends to have a cumulative effect: scandal breeds scandal, precisely because each scandal further sharpens the focus on the credibility and trustworthiness of political leaders'. This focus becomes incorporated into the political cycle as political parties and their leaders pledge to improve standards of conduct after their opponents fail the credibility test.

Just as one of Howard's major campaign themes before winning government in 1996 was around this issue, Labor leader Kevin Rudd campaigned on increasing accountability and released his own version of the ministerial code of conduct after winning government in 2007. Both Howard and Rudd criticised previous governments for condoning lower standards of ministerial behaviour and promised reforms once in government. First-term governments are particularly vulnerable as they provide test cases for the effectiveness of the new reforms, compounded by ministerial inexperience; however, after a few 'scalps', prime ministers lower the standards themselves. After Howard lost a few ministers in his first term, he changed tactics. While inexperienced Labor ministers did not succumb to the same fate in their first term as their Coalition predecessors, Rudd did lose his Defence Minister, Joel Fitzgibbon, after the Defence Department conducted unauthorised covert investigations into his friendship with a businesswoman. While this was not deemed sufficient to warrant resignation, it invited increased media scrutiny and it emerged that his brother, who headed a health fund, had met department officials to pursue business opportunities. Fitzgibbon resigned to 'protect the integrity of the government' (The Australian, 4 June 2009). Months later, Environment Minister, Peter Garrett, was criticised for his department's administration of the Home Insulation Program, which resulted in several deaths and house fires; in an election year, Garrett was demoted, remaining in the ministry but with his portfolio downgraded.

Backbenchers are better placed than ministers to successfully emerge from scandals because they do not have to front the media in the execution of their normal duties. Furthermore, public discussion is also limited: unknown backbenchers are less interesting unless the transgression is particularly unusual. The media is generally very aggressive with ministers, but quickly loses interest in backbenchers, and is less likely to pursue leads involving them in the first place. In most cases it is not the transgression or its magnitude that causes the scandal, but the standing of the politician that attracts media attention.

\section{The Role of the Media}

There is a tendency to simplistically view the media as one homogenous entity, particularly in Australia where media ownership is so concentrated, and even 
more so in relation to politics, which is principally covered by a relatively small Canberra Press Gallery. Scandals, however, consist of multiple narratives and, for public discussion to be genuinely fostered, there need to be contested interpretations. As Lull and Hinerman (1997) observe, scandals are polysemicthat is, they are never uniformly interpreted. While there may be a diverse range of opinions expressed in editorials, political columns, letters to the editor and panel discussions on radio and television programs after the facts have emerged, in the actual reporting of the incident in the initial stages of the scandal a 'pack mentality' can easily develop. Once the scandal breaks, the media's objectivity can become compromised in the sense that their interest is in finding new information to provide more evidence of guilt rather than objectively considering the possibility of innocence (Garment 1991). It is the nature of contemporary media competition, with each media organisation worried about being 'scooped' by rivals. As Tiffen (1999) observes, unlike in a court of law, in the media, evidence presented is not subject to clear rules, and thus the timing is only dependent on availability, opportunity and an erratic sense of newsworthiness. Tiffen also notes another important difference between media coverage and judicial due process: media coverage shifts focus as issues develop and can lose clarity about what the alleged offence actually is.

There has also been a 'tabloidisation' of existing media, as broadsheet newspapers have gone downmarket in an attempt to arrest declining revenues (with a particular interest in sex scandals), which has contributed to increasing personalisation of politics (Dobel 1998; Tumber 2004; Tumber and Waisbord 2004a, 2004b). Tumber and Waisbord describe 'tabloidisation' as the focus on titillation, drama, rumour and sensationalism, at the expense of substance and the higher journalistic standards of rigour and veracity. Media advisors to politicians are complicit in this process, with press releases and rehearsed 'sound bites' conforming to, and thus perpetuating, tabloid standards. Gamson (2004) argues that market forces have pressured mainstream news organisations to adopt tabloid-style topics and presentation strategies. Tabloidisation is not exclusive to the newspaper industry, with television news programs also following similar trends, aided by spin doctors and shrinking audience attention spans. Increased competition from cable news channels that have successfully embraced tabloidstyle presentation techniques has persuaded higher-quality news programs to do the same. As Williams (1998) observes, unlike complex policies, personal wrongdoing can be simply reported and is more likely to generate interest.

Unlike the traditional inverted-pyramid style of news reporting - that is, where articles are structured from the beginning with the most important point, continuing to the least important-scandals are narrated like a story (Bird 1997). The media imposes narrative frames providing characters, structure and longevity (Lull and Hinerman 1997). As Tomlinson (1997) notes, journalists use 
human-interest angles to appeal to the widest possible audience. Scandals are stories that can often overshadow the facts in attempting to arouse the curiosity of the widest possible audience, who then seek more information from the media (Lull and Hinerman 1997). In this way, narrativisation encourages speculation, as the emphasis shifts from reporting what actually happened to debating what will happen next. Thus, the initial transgression can become less and less important as the scandal ensues, to the point where it is (almost) forgotten.

The plot and character developments resemble familiar storylines and structures to facilitate greater identification from the audience, while the storylines themselves are quite simple albeit sensationalised. Kenski (2003) observes that scandals focus on the dramatic and are framed in terms of winning and losing, where the politician's status or reputation is at stake; however, as briefly mentioned in the previous section, there is never only one storyline (in major scandals at least). Williams (1998) argues that major political scandals do not take the form of a single, unbroken narrative, as there is competition between the various players - such as the initiator, the transgressor, the media and political opponents - for ownership and control of the scandal. Williams (1998, 128) contends that scandals consist of 'disconnected, fragmented, overlapping, multiple narratives'. The audience or, more precisely, audiences are also disconnected, fragmented and overlapping.

One notable trend is for journalists to use scandals to psychoanalyse leaders and to raise questions of judgment that have only tenuous connections with ministerial accountability. The prime minister's political judgment in selecting and retaining the minister is then called into question. If anything, the administrative errors or issues more directly related to the minister's portfolio or performance are easier to get away with, as there are more people to blame and chains of events are often complicated. It is more difficult for the largely politically uninterested public to follow these than, for example, the more salacious sex scandals. Journalists sometimes also assume the role of amateur psychologist. Former leader of the Australian Democrats turned Labor frontbencher Cheryl Kernot (2002, 150), herself subject to many scandals, is unsurprisingly critical: 'The editor of the Canberra Times, Jack Waterford, voices concerns about a different trend: that of psychological speculation in political reporting, where journalists, as amateur psychologists, theorise at length on the motives for politicians' actions and decisions; this is often as a substitute for factual reporting.'

In most cases, it was not the opposing party that publicly initiated and aggressively pursued the issue. The media has often uncovered and publicised the information, as in the cases of Helen Coonan (the Sydney Morning Herald's Mark Riley); John Sharp (the Nine Network's Laurie Oakes); Chris Ellison (the Sunday Telegraph's Peter Rees, with investigative committee work by Labor Senator Robert Ray); and Peter Reith (The Canberra Times's Emma MacDonald). 
Most of these scandals involved the misuse of taxpayer-funded entitlements, which supports the argument that the opposition has been reluctant to become too overtly involved, lest their own practices be made public. While a scandal might be damaging for its subject, it can also harm the initiator, as the targeted politician has someone (the initiator) to identify and blame. That does not mean, however, that the media might not receive tips or leaks from the opposing party.

While the emergence of new and alternative media has been cited as a factor in the proliferation of political scandals in contemporary politics, its role in Australian politics has been limited. It is generally the 'old' media that breaks scandals and is instrumental to their continued momentum; however, the 'old' media may still have been responding to competitive pressures caused by the changed media landscape. Even so, many politically focused blogs continue to publish rumours and innuendo that have not been repeated in the mainstream media. There are other important differences between the Australian media culture and the American media culture, upon which much of the scandological theory is based. Australia does not have a prevalence of locally based talk shows or topical comedy programs, and has only a couple of 24-hour news channels (and even those include many overseas news programs and stories). Local and talkback radio are prominent, but do not operate on a 24-hour news cycle in the same way. Furthermore, as previously mentioned, media ownership is more concentrated in Australia and competition is thereby reduced. In these respects, Australian politicians enjoy more protection than their American and British counterparts.

\section{Conclusion}

Scandals are never exactly the same partly because the seriousness of the offence is not always the best predictor of the outcome, and actions can produce differential consequences depending on the context (Tiffen 1999). As Tiffen (1999) observes, in the 'court of public opinion' penalties vary and there is inconsistency between the punishments, which are often disproportionate to the severity of the offences and related more to political expediency or accidents of circumstance. Public opinion itself is inconsistent and there are varying points of view amongst the public. Furthermore, it depends when this court of public opinion is in session - that is, the timing of the offence. It also depends on whether the court is distracted by other issues, which is again related to the timing of the event. Thus, luck can be a factor. The outcome will depend on the status of the politician involved and how distracting the incident is to the party's polling performance more broadly. Again, internal party dynamics appear to be an important factor, specifically the authority that a politician wields within the party and how powerful his or her factional allies 
and opponents are. While it is difficult to definitively ascertain, it appears that many scandals emanate from within the politician's own party. With limited ministerial positions for ambitious backbenchers, the goal is often to damage the standing of the politician within the party rather than in the electorate.

Ministers can and do come back and scandals need not be politically damaging in the first instance; however, there is a cumulative effect, and multiple scandals can be politically fatal, as politicians become more susceptible and also more open to scrutiny. Kernot is a classic example of how frequent scandals raise questions about a politician's competence, as the 'benefit of the doubt' is gradually exhausted. Ultimately, the scandals discussed here were viewed through the prism of leadership - that is, while the minister's response was important to some degree, in each case the reactions of the leader deeply affected the political dynamics. Most ministers initially resist calls for resignation, opting for some form of explanation, and the focus shifts to the prime minister and how he or she handles the situation. This becomes the primary focus of the scandal, with the accountability of the minister of secondary concern.

\section{References}

Apostolidis, P. and J. A. Williams (eds). 2004. Public Affairs: Politics in the Age of Sex Scandals. Durham, NC: Duke University Press.

Bird, S. E. 1997. 'What a Story! Understanding the Audience for Scandal'. In Media Scandals: Morality and Desire in the Popular Culture Marketplace, eds J. Lull and S. Hinerman. Cambridge: Polity Press.

Clark, A. 2003. Scandal: The Sexual Politics of the British Constitution. Princeton, NJ: Princeton University Press.

Dobel, J. P. 1998. 'Judging the Private Lives of Public Officials'. Administration and Society 30(2): 115-42.

Gamson, J. 2004. 'Normal Sins: Sex Scandal Narratives as Institutional Morality Tales'. In Public Affairs: Politics in the Age of Sex Scandals, eds P. Apostolidis and J. A. Williams, pp. 39-68. Durham, NC: Duke University Press.

Garment, S. 1991. Scandal: The Culture of Mistrust in American Politics. New York: Times Books.

Kenski, K. M. 2003. 'The Framing of Network News Coverage during the First Three Months of the Clinton-Lewinsky Scandal'. In Images, Scandal, and Communication Strategies of the Clinton Presidency, eds R. E. Denton jr and R. L. Holloway. Westport, Conn.: Praeger. 
Kernot, C. 2002. Speaking for Myself Again: Four Years with Labor and Beyond. Sydney: HarperCollins.

Logue, J. 1988. 'Appreciating Scandal as a Political Art Form, or, Making an Intellectual Virtue of a Political Vice'. In The Politics of Scandal: Power and Process in Liberal Democracies, eds A. S. Markovits and M. Silverstein. New York: Holmes \& Meier.

Lull, J. and S. Hinerman. 1997. 'The Search for Scandal'. In Media Scandals: Morality and Desire in the Popular Culture Marketplace, eds J. Lull and S. Hinerman. Cambridge: Polity Press.

McKeown, D. 2009. A Survey of Codes of Conduct in Australian and Selected Overseas Parliaments. Canberra: Department of Parliamentary Services.

Markovits, A. S. and M. Silverstein (eds). 1988. The Politics of Scandal: Power and Process in Liberal Democracies. New York: Holmes \& Meier.

Neckel, S. 2005. 'Political Scandals: An Analytical Framework'. Comparative Sociology 4(1-2): 101-14.

Thompson, J. B. 2005. 'The New Visibility'. Theory, Culture and Society 22(6): 31-51.

Tiffen, R. 1999. Scandals: Media, Politics and Corruption in Contemporary Australia. Sydney: UNSW Press.

Tomlinson, J. 1997. "And Besides, the Wench Is Dead": Media Scandals and the Globalization of Communication'. In Media Scandals: Morality and Desire in the Popular Culture Marketplace, eds J. Lull and S. Hinerman. Cambridge: Polity Press.

Tumber, H. 2004. 'Scandal and Media in the United Kingdom'. American Behavioral Scientist 47(8): 1122-37.

Tumber, H. and S. R. Waisbord. 2004a. 'Political Scandals and Media across Democracies, Volume I'. American Behavioral Scientist 47(8): 1031-9.

Tumber, H. and S. R. Waisbord. 2004b. 'Political Scandals and Media across Democracies, Volume II'. American Behavioral Scientist 47(9): 1143-52.

Uhr, J. 1998. 'Howard's Ministerial Code'. Res Publica 7(1): 1-11.

Williams, R. 1998. Political Scandals in the USA. Edinburgh: Keele University Press. 